\title{
The Realization of Casual Conversation Features of EFL Learners
}

\author{
Andi Tenry Lawangen Aspat Colle ${ }^{1}$ \\ ${ }^{1}$ Universitas Negeri Semarang \\ email: tenry.colle@gmail.com
}

\begin{abstract}
This study was descriptive qualitative, which aimed at explaining the casual conversation features between two learners and its functions in terms of negotiation of meaning, spontaneity, interpersonal, and interactivity. To obtained data, firstly, recording the conversation was done, continued by transcribing, coding, and the last was analyzing the findings. The findings showed this conversation was dominated by exchange information and idea between the speakers rather than exchanging feelings because logico-semantic appeared more dominant than interpersonal negotiation. In terms of spontaneity feature, it could be shown by the learners' laughter during the conversation. Meanwhile, interpersonal features that occurred were filled pauses, repetition, false start, and chunk. Then, interactivity features were turn-taking, back-channeling, and discourse markers. Also, those number of features and its functions implied in this casual conversation have an essential contribution. For instance, filled pauses can be used to take time to think of what is going to say. This study suggests that further research investigates how cultural and gender affect the speakers' spoken features in monologue and dialogue speech, and also both formal and non-formal situations.
\end{abstract}

Keywords: Conversation, Negotiation, Spontaneity, Interpersonal, Interactivity.

\begin{abstract}
Abstrak
Penelitian ini adalah penelitian kualitatif deskriptif yang bertujuan untuk menjelaskan aspek percakapan yaitu negosiasi makna, spontanitas, interpersonalitas, dan interaktivitas antara dua mahasiswa berserta fungsi dari tiap-tiap aspek. Untuk memperoleh data, percakapan direkam, dilanjutkan dengan mentraskrip rekaman, mengkode dan yang terakhir menganalisis hasil temuan. Hasil penelitian menunjukkan bahwa percakapan ini didominasi oleh pertukaran informasi dan ide antara pembicara daripada bertukar perasaan, karena logika semantik lebih dominan daripada negosiasi antarpribadi. Dalam aspek interpersonal, aspek ini diungkapkan oleh tawa selama percakapan terjadi. Untuk aspek spontanitas yang muncul adalah jeda (filled pause), pengulangan (repetition), false star, dan chunk. Kemudian aspek interaktivitas adalah turn-taking, back-channeling, dan penanda wacana (discourse markers). Aspek-aspek tersebut dan fungsinya yang tersirat pada percakapan ini memiliki peranan penting. Misalnya, jeda (filled pause) berfungsi untuk mendapatkan waktu tambahan memikirkan apa yang akan dikatakan selanjutnya. Penulis menyarankan, peneliti selanjutnya
\end{abstract}


menjelaskan bagaimana budaya dan gender mempengaruhi aspek percakapan dalam konteks monolog dan dialog, atau situasi formal dan tidak formal.

\section{Kata Kunci: Percakapan, Negosiasi, Spontanitas, Interpersonalitas, Interaktivitas}

\section{INTRODUCTION}

Language is the most fundamental aspect of communication, where people use it as a tool to express their ideas and felling. Bussmann (2006, p.627) says that "language is a vehicle for the expression or exchanging of thoughts, concepts, knowledge, and information as well as the fixing and transmission of experience and knowledge." People deliver meaning and feeling through language. Furthermore, Wardhaugh (2006) states that communication is a social activity that requires coordinating efforts of two or more individuals. Thus, communication involves more than one person, the speaker, and the interlocutors.

Communication can be delivered in two ways, written and spoken communication. Spoken language, such as casual conversation differs from the written language because there are various spoken features which are differed from the written form. Those features are the negotiation of meaning (logico-semantic and interpersonal), spontaneity (filled pauses, repetition, false start and backtracking, incomplete utterance and chunks), interpersonal (laugh), and interactivity (turn-taking, back-channeling, interruption, overlapping, and discourse markers).

The number of related studies has been done such as repetition (Rieger, 2003; Bilal, Mavasoglu, \& Erdogan, 2010; Rabab'ah, 2013), back-channeling (Kjellmer, 2009; Li et al., 2010), Japan back-channeling (Cutrone, 2010), Persian back-channeling (Sharifi and Azadmanesh, 2011; Aghblagh, 2017). Those features of spoken language are essential because if these features are neglected, the flow of conversation will be interrupted or stopped right away. Thus, through this descriptive qualitative study, those features and their functions were analyzed to explain how EFL learners communicate each other.

\section{METHOD}

This study was qualitative research and used descriptive research as its framework. In other words, the results of the data analysis of meaning negotiation, spontaneity, interpersonal, and interactivity in the casual conversation were presented in the form of lingual units (words, phrases, sentences) rather than in the form of numbers. It is in line with Vanderstoep and Johnston's statement (2009, p. 167), that "the purpose of qualitative research is more descriptive than predictive." The subject of this study were two non-native English learners of a state university in Semarang.

In this study, the researcher used a recording method to obtain the data. The recording method was used in recording the conversation of the participants in real condition. Since the object of this data is the casual conversation between two nonnative English learners, there were some procedures in analyzing the data; firstly, recording the participants' conversation. Secondly, transcribing the conversation in detail. Thirdly, coding the features which were indicated the negotiation of meaning, spontaneity, interpersonal, and interactivity. Lastly, analyzing those found features. 


\section{FINDING AND DISCUSSION}

Based on the data analysis, there were four spoken features in the casual conversation found. They were negotiation of meaning (logico-semantic and interpersonal), spontaneity (laugh), spontaneity (filled pauses, repetition, false start, and chunk), and interactivity (turn-taking, discourse markers, and back-channeling).

\section{Negotiation of Meaning in Casual Conversation}

Communicate means to negotiate meaning; when someone communicates, they carry out logico-semantic and interpersonal negotiation. Carrying out logico-semantic negotiation means exchanging information or ideas while carrying out interpersonal negotiation means exchanging attitudes or feelings. The negotiation of meaning used in this conversation could be seen in the following table.

Table 1: Negotiation of meaning in conversation.

\begin{tabular}{|c|c|c|c|c|}
\hline \multirow{2}{*}{ Speakers } & \multirow{2}{*}{ Moves } & \multicolumn{2}{|c|}{ Negotiation (\%) } & \multirow{2}{*}{$\%$} \\
\cline { 3 - 4 } & $\begin{array}{c}\text { Logico- } \\
\text { Semantic }\end{array}$ & Interpers. & \\
\hline Mrs. A & 200 & $\begin{array}{c}162 \\
(81 \%)\end{array}$ & $\begin{array}{c}38 \\
(19 \%)\end{array}$ & 100 \\
\hline Miss. B & 153 & $\begin{array}{c}129 \\
(84,31 \%)\end{array}$ & $\begin{array}{c}24 \\
(15,68 \%)\end{array}$ & 100 \\
\hline Total & 353 & $\begin{array}{c}291 \\
(82,43 \%)\end{array}$ & $\begin{array}{c}62 \\
(17,56 \%)\end{array}$ & 100 \\
\hline
\end{tabular}

It could be seen that there are 353 moves involved in the casual conversation between Mrs. A and Miss. B. Mrs. A produced 200 moves, which consist of 162 (81\%) logico-semantic negotiations and 38 (19\%) interpersonal negotiation appeared. Meanwhile, Miss. B produced 153 moves, which consist of 129 (84, 31\%) logicosemantic negotiation, and $24(15,68 \%)$ interpersonal negotiation appeared. Thus, regarding the negotiation of meaning used between Mrs. A and Miss. B within the conversation, logico-semantic negotiation became the most prominent used 291 (82, $43 \%$ ) and followed by interpersonal negotiation $62(17,56 \%)$. It means that this casual conversation was dominated by exchange information and idea between Mrs. A and Miss. B.

\section{Spontaneity in Casual Conversation}

There are some aspects of spontaneity in spoken text or language. They consist of filled pauses, repetition, false start, incomplete utterance, and chunks. In this study, some features found in the data were filled pauses, repetition, a false start, and chunk.

\section{$\underline{\text { Filled pause }}$}

Filled pause is characterized by the expression, such as: um, $\mathrm{mm}$, uh, err. It is other utterances that do not include in the message of the speech. The filled pause can be placed at the beginning, middle, and last speech. The example of a filled pause could be seen in the following conversation:

Excerpt 1

\begin{tabular}{|c|c|c|c|}
\hline 8.b & Miss. B & : & $\begin{array}{l}\text { Of course, about looking for } \\
\text { jobs as a lecturers or teacher. }\end{array}$ \\
\hline 9.a & Mrs. A & : & $\begin{array}{l}\text { Well, Frankly speaking, I made } \\
\text { it once when I applied to Dian } \\
\text { Nuswantoro university as a } \\
\text { language trainer in CFLT. } \\
\text { From there, I got the } \\
\text { opportunity to handle several } \\
\text { classes of Bahasa Inggris } 1 \text { for } \\
\text { the first semester students and } \\
\text { Bahasa Inggris } 2 \text { for second } \\
\text { semester students. mmm The } \\
\text { material is quite easy. So I can } \\
\text { tackle. I began teaching in } \\
\text { 2001 and I was only the } \\
\text { assistant there. I think there is } \\
\text { no professor without being the } \\
\text { amateur at first. mmm We need } \\
\text { to learn Riz. And for the } \\
\text { application letter (mmm) there } \\
\text { are many example in the }\end{array}$ \\
\hline
\end{tabular}


internet ... just copy the one that suits you.

The function of filled pause $\mathrm{mmm}$ in this conversation is to hold a conversational turn, which means that Mrs. A wanted to take enough time to think and then to continue her conversation. This finding is also supported by Zhang (2010) who explained, the words I mean, you know, $\mathrm{mmm}$ are used to gain a little time to think what is going to say next by holding the turn.

\section{$\underline{\text { Repetition }}$}

Repetition appears to involve restarting the utterance from the beginning, whether a syllable, a lexical word, a phrase, even a sentence. A speaker repeated their words to have self-repair and also gain time to plan or formulate what to say next. In the conversation, the speakers did some repetitions as follows:

Excerpt 2

21.a Mrs. A : I need to look for it then... I forgot where I put the file. Aaa (rising intonation). We can ask Ronnie or Rizky Rohmawan for the file. Do you have their contact?

21.b Miss. B : Yes, I have their numbers. I will try to contact them on .... WA. Hopefully they ... they still save the PowerPoint so that we can copy it. We really need it for doing the test.

Repetition of the word they in Miss. B's utterances indicate that she is taking time to plan what she wants to say in the next statements. Kovac (2016) explained that although repetition categorizes as a form of speech disfluency, however, it is one of the communication strategies that can be used by the learners to gain additional time and to remain in the interaction despite the learners' language limitation.

Further, the repetitions in some parts of the conversation have another function as can be seen in the following conversation: Excerpt 3

$\begin{aligned} \text { 28.a Mrs. A : } & \text { Yup... ha, it's nicer here. } \\ & \text { mmm never before did I } \\ & \text { come to the library } \\ & \text { together with you ha... } \\ & \text { that's why I can manage } \\ & \text { my boredom now. Let me } \\ & \text { join you if you go here } \\ & \text { again, please. }\end{aligned}$

28.b Miss. B : Are you busy tomorrow? Tomorrow I' come I'll come here again. I want to revise my methodology.

29.a Mrs. A : Crispy mushroom...? I can cook it for ... I can cook myself for you...
Miss. B : It sounds good! Hmm ... Anyway we have talked busy about foods. That makes me feel hungry.. What time is it now?

Repetition in conversation 28.b (I' come I'll come) and 29.a (I can cook it for ... I can cook myself) has a function as selfrepair. The speakers repeat their utterances because they are realized if they are making a mistake in grammar usage. Thus, they repeat the correct one.

\section{$\underline{\text { False Start }}$}

Cameron (2001) argues it is not surprising that speakers often make false starts because they have to produce their 
contributions in real-time with minimal planning. False starts can adjust the grammatical structure to the right expression of the meaning. The example of false start could be seen in the following conversation

Excerpt 4

$\begin{array}{ll}\text { 17.a Mrs. A : } & \text { Haaaaaa, what } \\ & \text { assignment do you mean? } \\ & \text { Ahhhh, I remember. Last } \\ & \text { Monday I got the project to } \\ & \text { present journal under the } \\ & \text { topic of speech act but I } \\ & \text { have some time to prepare } \\ & \text { it. I'll do it this weekend. } \\ & \text { Emm, Moreover, my turn } \\ & \text { is on 11 meeting. Do you } \\ & \text { comprehend about speech } \\ & \text { act Ris? }\end{array}$

17.b Miss. B : No at... Not at all. Oh ya, I reme I remember that last semester Indah presented about the same topic. Maybe you can ask her. Well, I will present a journal about politeness theory, but I haven't found the journal yet. Do you have any journal about politeness theory?

No at ... not at all was uttered by Miss. $\mathrm{B}$ at the beginning of her turn to speak, and it could be categorized as a false start. Miss. $B$ made the wrong start and repeated the words to adjust the grammatical structure to utter the right expression of the meaning.

\section{Chunks}

The term chunk refers to several words that are customarily used together in a fixed expression, such as in my opinion, to make a long story short, how are you? or know what I mean?. According to Lackman (2011), there are three types of chunks, which are: a. Collocations: words of the four main parts of speech that go together, usually, but not always, two words. (e.g., take in, first time, a little bit). The categories of collocation are adverb + adjective, adjective + noun, noun + noun, verb + noun, verb + expression with preposition, and verb + adverb

b. Fixed expressions: expressions that cannot be changed or can only be changed minimally. Most fixed expressions are idiomatic, or are those used in polite speech (e.g., take the bull by the horns, how is it going?).

c. Semi-fixed expressions: expressions that have at least one slot into which several different words or phrases can be inserted. (e.g., It didn't take the..., have you taken into account...)

The usage of chunks in Mrs. A and Miss. $B$ conversations could be seen in the following conversation:

Collocation:

Excerpt 5

37.a Mrs. A : No worry... I am a good cook. Hihihi..., if I don't have time to cook, there are sooooo ... many restaurants and food courts near my house. They provide any kinds of menu ... what's your favorite?

37.b Miss.B : Sate Padang! Oh this food makes me really crazy! It's so hard for me to find it in Semarang.

38.a Mrs. A : There is one near my house. Wanna try with me? Visit sometime.... the taste is similar to sate ayam in Semarang, perhaps the spicy is not the original one, I think.

38.b Miss.B : Hmmm I wanna try the original Sate Padang or is there another option for me? I like mie ayam, meatball, and fried rice 
39.a Mrs. A : Crispy mushroom...? I can cook it for ... I can cook myself for you...

39.b Miss.B : It sounds good! Hmm... Anyway we have talked busy about foods. That makes me feel hungry.. What time is it now?

From the conversation, some collocation found are:

$\begin{array}{lll}\text { Adjective + noun } \quad: & \text { good cook, any } \\ & \text { restaurants, my } \\ & \text { house, near my } \\ & \text { house } \\ \text { Noun + noun } & \text { food courts, } \\ & \text { crispy } \\ & \text { mushroom } \\ \text { Adverb + adjective }: \text { really crazy, so } & \text { hard } \\ \text { Verb + adverb } \quad: \text { talked busy }\end{array}$

Fixed expression Semi-fixed expression: Excerpt 6

\begin{tabular}{|c|c|c|}
\hline 6.b & Miss. B & $\begin{array}{l}\text { Well, I haven't done the } \\
\text { revision. I will revise it } \\
\text { from the research questions } \\
\text { and then the objectives of } \\
\text { the study. The topic of my } \\
\text { proposal is Cooperative } \\
\text { Principle in the Talk Show. } \\
\text { What about you mba, } \\
\text { what's the topic of your } \\
\text { proposal? }\end{array}$ \\
\hline 7.a & Mrs. A & $\begin{array}{l}\text { Haaaaaa ... I suppose to } \\
\text { talk about forensic } \\
\text { linguistics but it's still up } \\
\text { in the air.. His, however, } \\
\text { is new in SFL. Otherwise, } \\
\text { I may write about appraisal } \\
\text { in my thesis proposal. } \\
\text { mmm As a matter of fact, I } \\
\text { just want to make it easier } \\
\text { for myself. }\end{array}$ \\
\hline
\end{tabular}

'It's still up in the air' in the conversation above classified as a fixed expression because it is an idiom. The meaning of this idiom is uncertain or unresolved, often because other matters have to be decided first, not yet settled or finalized, unsure, full of doubt, not yet decided. Thus, this idiom used to say that something is still not decided and that we are still waiting to receive someone's decision about a situation or that we are waiting for more information that will allow us to decide it.

Meanwhile, "What's the topic of $+\ldots$ ". classified as a semi-fixed expression because the structure of this sentence still can be changed based on the context of the usage. Example: What's the topic of + your presentation/speech/ discussion today, etc.

\section{Interpersonal in Casual Conversation}

The conversation is not merely the exchange of information, but it has a strong interpersonal function. It serves to establish and maintain group solidarity. Laughter can be used to set up and regulating social relationships, usually in spoken interaction. This feature takes place between speakers who are familiar with each other.

Excerpt 7

\begin{tabular}{|c|c|c|c|}
\hline $9 . b$ & Miss.B & & $\begin{array}{l}\text { Wow, } 2001 \text { ? It means that } \\
\text { you have teach English for } \\
16 \text { years. Well, I have no } \\
\text { experiences. I have to learn, } \\
\text { especially from you heee } \\
\text { (short laughed). Anyway, } \\
\text { how many retaken class do } \\
\text { you have this semester? }\end{array}$ \\
\hline $10 . \mathrm{a}$ & Ms. A & : & $\begin{array}{l}\text { hemm, I take } 2 \text { classes Riz. } \\
\text { Pragmatics and Discourse } \\
\text { Study. I didn't get } \\
\text { Pragmatics subject when I } \\
\text { was in undergraduate degree } \\
\text { so that I need to study about } \\
\text { it more. I have already } \\
\text { gotten AB, but I need to } \\
\text { know more about this } \\
\text { subject,.... }\end{array}$ \\
\hline 10.b & Miss. B & ${ }^{\circ}$ & $\begin{array}{l}\text { me? I take } 4 \text { classes, ha } \\
\text { (short laughed) discourse of } \\
\text { course, } \\
\text { semantics pragmatics, } \\
\text { sociolinguistics. } \\
\text { schedule is full on Monday }\end{array}$ \\
\hline
\end{tabular}




\section{and Thuesday. And of course I will have so many assignments, and at the same time I'm busy with my thesis. Can you imagine? \\ 11.a Ms. A : Ho ... ho .. ho, great, how great your strugle! So proud of you, Riz.. that must be so tiring..}

\section{Interactivity in Casual Conversation}

Interactivity means that the conversation is interactive, and speakers interact by taking turns to speak, keeping silent when others are speaking, interrupting at times and, signaling their amusement by grunts, laughs and chuckles, back-channeling to register that they are following the speaker's drift (Thornbury, 2005). Thus, to know whether the interactivity in a conversation runs well or not could be analyzed based on some aspects such as turn-taking, back-channeling, interruption, overlapping, and discourse markers. In this conversation, interactivity aspects that occurred were turn-taking, backchanneling, and discourse markers.

\section{Turn-taking}

In conversation, there is a situation when a speaker takes the chance to speak that is turn-taking. Turn-taking allows speakers to make conversation smoothly, so there will not be a dominant speaker in the conversation. The first speaker utters something which is then followed by another speaker. It may make a simultaneous conversation. The result of the turn-taking occurred in the conversation is provided in the table:
Table 2. Turn-taking in conversation.

\begin{tabular}{|c|c|c|}
\hline Speaker & Turn-taking & $\%$ \\
\hline Mrs. A & 40 & 50 \\
\hline Miss. B & 40 & 50 \\
\hline Total & 80 & 100 \\
\hline
\end{tabular}

From the table, it can be seen that there were 80 taking turn occurred in the conversation where Mrs. A had 40 turns in speaking, and Miss. B also had 40 turns in speaking. In the conversation, Mrs. A acted as the first speaker, the person who initiates the conversation for the first time. Moreover, Miss B performed as the second speaker.

The example of how the turn changed from Mrs. A to Miss. B could be seen in excerpt 8, as follows:

\section{Excerpt 8}

$\begin{aligned} \text { 1.a Mrs. A : } & \begin{array}{l}\text { Risky, how was your } \\ \text { proposal examination? I was }\end{array} \\ & \text { so sorry that I couldn't come } \\ & \text { to see your proposal } \\ & \text { examination. I regretted it, } \\ & \text { really... who are there, as } \\ & \text { the examiners? } \\ \text { 1.b Miss B : } & \text { The examiners were Miss. } \\ & \text { Wiwi, Mr. Yan, Mr. Faridi, } \\ & \text { and Mr. Sofwan. } \\ & \text { Unfortunately, Mr. Faridi } \\ & \text { and Mr. Sofwan didn't } \\ & \text { come. So, I meet them after } \\ & \text { the exam. }\end{aligned}$

From the conversation above, Mrs. A ended his turn by asking and giving a clue by saying, who are there, as the examiners? Mrs. A hoped that Miss. B wanted to respond to her question. So Miss. B started his turn by answering Mrs. A's question. The kinds of turn-taking in excerpt 8 is turn-taking by giving nomination. Mrs. A finished her utterance by providing a question to Miss. B. 
Meanwhile, another kind of turn-taking could be seen in the following excerpt as follows:

\section{Excerpt 9}

1.b Miss. B : The examiners were Miss. Wiwi, Mr. Yan, Mr. Faridi, and Mr. Sofwan. Unfortunately, Mr. Faridi and Mr. Sofwan didn't come. So, I meet them after the exam.

2.a Mrs. A : ha? (intonation raised) So you did the exam for twice? Was that the consequence of their absence? I couldn't even imagine if I were you... it must have been so hard for you, Riz....

From the excerpt above, it is showed that Miss. B ended his turn by giving her statement without giving another clue or another direct answer to Mrs. A. Afterward, Mrs. A started her turn by giving a response and making an opinion of Miss. B's statement.

\section{Discourse Marker}

Schiffrin (1987) defines discourse markers as sequentially dependent elements that bracket units of talk. These units help to determine the choice of DM and the meaning speakers intend, and listeners infer. It focused primarily on expressions and, because, but, I mean, now, oh, or, so, then, well, and y'know.

After analyzing the conversation, discourse markers occurred several times that would be provided in the following conversation:

\section{Excerpt 10}

32.b Miss B : Maybe, you can ask him next time next time. Unfortunately, I can't help you. Anyway. Next week will be long weekend. I have plan to go to Jogja with my cousin. Will you join us?

33.a Mrs. A : Well, no, thanks..... I'll go.... to bed... hahaha .... I don't wanna go anywhere. I am so tired with these things... we have lot of task, don't we?

The function of word well as a discourse marker used by Mrs. A indicates a rejection to soften the response of Miss. B offering. Excerpt 11

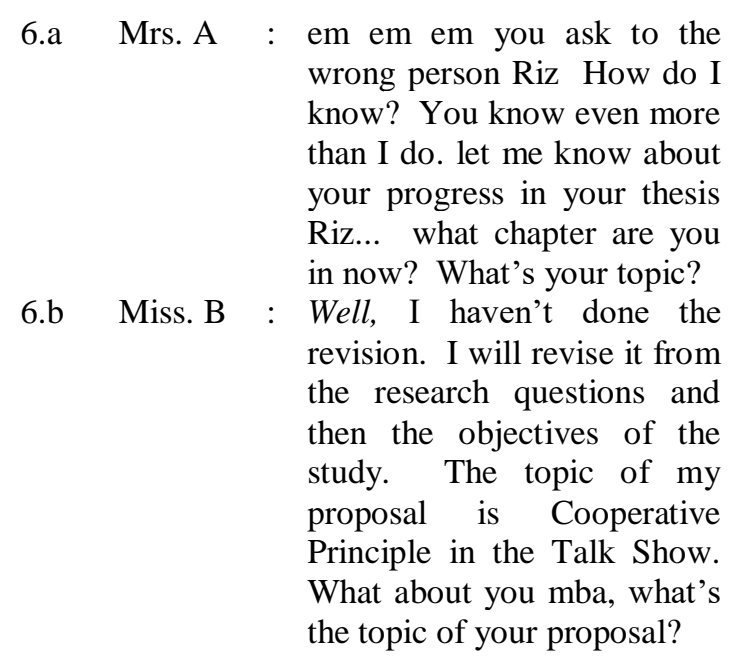

Well as a discourse marker is usually put at the beginning of a speaker's new turn to speak, similar to the conversation above, Miss. B used 'well' at the beginning of her turn to speak.

Excerpt 12

17.a Miss. A : Haaaaaa, what assignment do you mean? Ahhhh, I remember. last Monday I got the project to present journal under the topic of speech act but I have some time to prepare it. I'll do it this weekend. Emm, Moreover, my turn is on 11 th meeting. Do you comprehend about speech act Ris?

17.b Miss. B : No at... Not at all. Oh ya, I reme I remember that last semester Indah presented about the same topic. Maybe you can ask her. 
Well, I will present a journal about politeness theory, but I haven't found the journal yet. Do you have any journal about politeness theory?

Miss. B used well to indicate such transition in her utterance, which means she wanted to shift to a new topic (different aspects of a topic) from talking about speech acts as Mrs. A's article topic to politeness theory as her article topic.

\section{Excerpt 1}

15.a Mrs. A : I hope so. By the way, have you got your first assignment in ev (unfinished) every subject you take? hahaha... sorry for teasing you...

15.b Miss. B : Not yet. You know. I just finished my pro...posal examination 2 days ago. Today, I will start to revise the proposal first.. After the revision will be done, I will do the assignments. What about you mba, have you done?

Miss. B used you know to indicate that she assumed Mrs. A was somehow familiar with the information. It conveys the sense of You probably know/are familiar with this already; I know you're not dumb, but I'm telling you.

\section{Excerpt 14}

15.b Miss. B : Not yet. You know. I just finished my pro...posal examination 2 days ago. Today, I will start to revise the proposal first. After the revision will be done, I will do the assignments. What about you mba, have you done?

16.a Mrs. A : What the joke that you made? I didn't even have the idea to write the proposal then you ask me about revision? Hahaha... 16.b Miss. B : No, no. I mean I asked you about assignments in our retaken class. Not about proposal haa (short laugh) Have you done? May I borrow?

I mean is roughly equivalent to that is, in other words. In the conversation above, the function of I mean, which was uttered by Miss. B is to clarify her meaning in the previous conversation by adding an additional explanation.

\section{Excerpt 15}

$\begin{array}{cl}\text { 2.a Mrs. A : } & \text { ha? (intonation raised) So } \\ & \text { you did the exam for twice? } \\ & \text { Was that the consequence of } \\ & \text { their absence? I couldn't } \\ & \text { even imagine if I were you... } \\ & \text { it must have been so hard for } \\ & \text { you, Riz. } \\ \text { 2.b Miss. B : } \quad & \text { Yes, I did. Alh (unfinished) } \\ & \text { But Alhamdulillah, the } \\ & \text { second examination has } \\ & \text { done, and I feel free now. } \\ & \text { Now, I have to finish the } \\ & \text { revisions. But, I have not } \\ & \text { done it yet. Maybe } \\ & \text { tomorrow. }\end{array}$

The usage of the discourse marker now in Miss. B utterance indicates a different shift aspect of the topic from talking about thesis proposal examiners to the unfinished revision of the thesis proposal.

\section{Excerpt 16}

1.b Miss. B : The examiners were Miss. Wiwi, Mr. Yan, Mr. Faridi, and Mr. Sofwan. Unfortunately, Mr. Faridi and Mr. Sofwan didn't come. So, I meet them after the exam.

2.a Mrs. A : ha? (intonation raised) So you did the exam for twice? Was that the consequence of their absence? I couldn't even imagine if I were you, it must have been so hard for you, Riz. 
'Ha,' which used by Mrs. A categorized as feedback markers, which indicate that Mrs. A was surprised by Miss. B information about her proposal examination.

\section{Excerpt 17}

\begin{tabular}{|c|c|c|}
\hline 4.b & Miss. B & $\begin{array}{l}\text { I have finished the TOEFL } \\
\text { test two weeks ago. And I } \\
\text { got the certificate yesterday. } \\
\text { What about manuscript, } \\
\text { have you done? By the } \\
\text { way, I often meet Bu Bu } \\
\text { (repetition) Wuli in Campus. } \\
\text { Why didn't you met him? }\end{array}$ \\
\hline $5 . \mathrm{a}$ & Mrs. A & $\begin{array}{l}\text { Do you? Bu Wuli often } \\
\text { comes to campus because } \\
\text { she teaches there ha? I } \\
\text { hardly ever come to campus } \\
\text { after semester holiday, that's } \\
\text { why I haven't seen her yet.. } \\
\text { amm ... You asked me } \\
\text { about manuscript? Oh, } \\
\text { yeah, yeah. (repetition) I } \\
\text { joined it last month, but the } \\
\text { certificate? Hah, the } \\
\text { certificate? You make me } \\
\text { remember about the } \\
\text { certificate.. How to get the } \\
\text { certificate? }\end{array}$ \\
\hline
\end{tabular}

As a discourse marker, oh in Mrs. A' utterance indicates that she was thinking for a moment and then realized if she had not taken her manuscript certificate yet. $O h$ is categorized as a kind of interjection.

\section{Back-channeling}

As a part of the conversation and speech, back-channeling refers to words or phrases which provide feedback to the speaker by indicating that the listener is still involved in the conversation (Friginal \& Benjamins, 2009; Reinders, 2014). It can be verbal or non-verbal expressions such as the nodding of the head (White, 1989) or gazing (Young \& Jina 2004).

Back-channels are typically mono- or bisyllabic responses such as uh-huh, $\mathrm{mm}$, mhm, and yeah. (Gardner, 2001). After analyzing the conversation, backchanneling occurred in the conversation below:

\section{Excerpt 18}

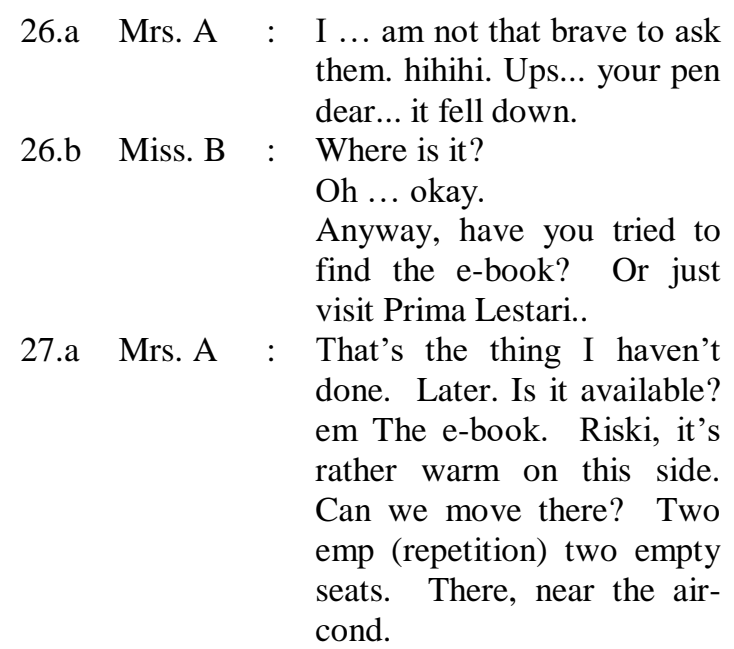

27.b Miss. B : Oh .... Okay. Let's go there.

The conversation contains a backchannel as the response from the listener to the speaker. It is marked by okay. In this conversation, it is used to give a signal of agreement. Mrs. A asked Miss. B to move to another seat near the air-conditioner. Miss. B said okay to deal with her. This function is in line with Cutrone's (2010) explanation that, back-channeling has a role as an agreement where the secondary speaker reacts to questions posed by the primary speaker by saying you're right, how true, I agree, right and yeah.

\section{CONCLUSION}

Through analyzing the negotiation of meaning, spontaneity, interpersonal, and interactivity of casual conversation, it can be concluded that the frequency of logicosemantic was higher than interpersonal negotiation. In the spontaneity feature, it was revealed by the learners' laughter during the conversation. Some features of 
spontaneity aspects performed by the speakers were filled pauses, repetitions, false starts, and chunks. Then, in terms of the interactivity aspect, some features occurred were turn-taking, backchanneling, and discourse markers.

\section{REFERENCES}

Aghblagh, M., M. (2017). Backchannelling in Persian: A study of different types and frequency of backchannel response. International Journal of Language Academy, 5(3), p. 181-189, DOI: http://dx.doi.org/10.18033/ijla.3575

Bilal, G. E. N. Ç., Mavasoglu, M., \& Erdogan, B. A. D. A. (2010). Types and functions of repetitions in the narrations of Turkish speakers of French. NOVITAS-ROYAL, 4(2).

Bussmann, H. (1998). Routledge Dictionary of Language and Linguistics. New York: Routledge.

Cutrone, P. (2010). The backchannel norms of native English speakers: A target for Japanese L2 English learners. Language Studies Working papers, 2, 28-37.

Gardner, R. (2001). When Listeners Talk: Response Tokens and Listener Stance. Amsterdam: J. Benjamins Publishing.

Friginal, E. and Benjamins, J. (2009).The language of out sourced call centers: A corpus-based study of cross-cultural interaction. International Journal of Corpus Linguistics, 15(4), 549-556.

Kovac, M. M. (2016). Repetitions as a communication strategy: A case study. Studies in English Language Teaching, 4(1), p.87-103.

Kjellmer, G. (2009). Where do we backchannel?: On the use of $\mathrm{mm}, \mathrm{mhm}$, uh huh and such like. International
Journal of Corpus Linguistics, 14(1), 81112.

Lackman, K. (2011). Teaching Collocations: Activities for vocabulary Building. KenLackman \& Associates Educational Consultants.

Rabab'ah, G. (2013). Strategies of repair in EFL learners' oral discourse. English Language Teaching, 6(6), 123-131.

Reinders, H. (2014). Backchannelling in the language classroom: improving student attention and retention with feedback technologies. The Journal of Language Learning and Teaching, 4(2), 84-91.

Rieger, C. I. (2003). Repetitions as selfrepair strategies in English and German conversations. Journal of Pragmatics 35 (1), 47-69.

Schiffrin, D. (1987). Discourse Markers. Cambridge: Cambridge University Press.

Sharifi, S., \& Azadmanesh, M. (2011). Speakers' cues inviting back channel responses in spontaneous Persian conversation. Us-China Foreign Language, 9.

Thornbury, S. (2005). Beyond The Sentence: Introducing Discourse Analysis. Macmillan Education.

Vanderstoep, S. W., \& Johnston, D. D. (2009). Research Methods for Everyday Life. USA: Jossey-Bass.

Wardhaugh, R. (2006). Introduction to Sociolinguistics: Fifth Edition. Blackwell.

Young, R F., \& Jina, L. (2004). Identifying units in interaction: Reactive tokens in Korean and English Conversations. Journal of Sociolinguistics, 8, 380-407. 